\title{
10分雨量データとXRAINデータを用いた 名古屋における強雨事例の雨域特性解析 CHARACTERISTICS OF RAINFALL AREAS OF HEAVY RAINFALLS IN NAGOYA SEEN IN 10-MINUTE AND XRAIN PRECIPITATION DATA
}

\author{
庄 建治朗 1 ・谷口 健司 2 ・冨永 晃宏3 \\ Kenjiro SHO, Kenji TANIGUCHI and Akihiro TOMINAGA \\ 1正会員 博 (工) 名古屋工業大学助教 ながれ領域（テ466-8555 名古屋市昭和区御器所町） \\ 2正会員 博（工） 金沢大学准教授 理工研究域環境デザイン学系（テ920-1192 金沢市角間町） \\ 3 正会員 工博 名古屋工業大学教授 ながれ領域（テ466-8555 名古屋市昭和区御器所町）
}

\begin{abstract}
Precipitation analysis for several heavy rainfalls that occurred in Nagoya City was performed based on 10-minute and hourly precipitation data. Rainfall distribution analyses showed that a rain band in the direction of the prevailing wind at middle levels was formed in 9 out of 10 major heavy rainfall events in past 56 years. The rain band consisted of aligned heavy-rain cells of about $5-10 \mathrm{~km}$ diameter that traveled successively along the rain band that was generated on a meso-scale convergence line. Also, the result of rainfall analysis using 10-minute precipitation data was compared to rainfall distribution based on XRAIN (X-band polarimetric RAdar Information Network, that was installed in Nagoya area in 2010) for the rainfall event in 2011 and its validity and precision was evaluated.
\end{abstract}

Key Words : 10-minute precipitation data, localized heavy rainfall, characteristics of rain bands, XRAIN (X-band polarimetric RAdar Information Network), Nagoya

\section{1.はじめに}

東海地域では，局地的に集中した豪雨による浸水被害 が近年度々発生している．特に，名古屋市を含む愛知県 西部では，人口や資産が低地の平野部に集積しているた め, その対策が切実に求められる. しかし, 空間的・時 間的に限られた範囲に集中した強雨は，その地域のメソ 気象が関係するため, 発生位置や時刻, 規模等を正確に 予測することは現段階では容易ではない。

こうした強雨の予測精度を高めるためには，過去にそ の地域で発生した強雨の事例について詳細な解析を行い, その特性を理解することが重要である，庄ら ${ }^{1)}$ は，愛知 県や名古屋市等により設置されている多数の雨量計によ る10分雨量の観測データを用い，2000年東海豪雨と2008 年8月末豪雨について, 詳細な雨域の動きと気象条件と の関係について解析した，その結果，愛知県西部に形成 されたメソ収束線で発生した降水セルが上空の風に流さ れ, 同一経路上を次々と通過することによって帯状の領 域に集中した大雨をもたらした様子が再現された。 また, 過去22年分の愛知県の雨量観測データの解析により, 知
多半島北部から名古屋にかけての領域で継続時間3時間 程度の大雨頻度が比較的高く, 東海豪雨と類似したメカ ニズムによる強雨がこの地域で時折発生している可能性 が示唆された．本稿では，これを検証するため，さらに 過去に遡って名古屋における強雨事例を抽出し, それら について降水セルの動きや帯状強雨域の出現位置・移動 速度等とメソ収束線の位置や中層風等の気象条件との関 係を調べ，2000年東海豪雨等と共通した特徵が見られる かを検討する．なお，10分雨量データの資料期間は10〜 25 年程度と限られていることから，より資料期間の長い 時間雨量データも利用し，できるだけ多くの強雨事例に ついて可能な解析を行って, 局地的な強雨の発生位置 ・ 規模等の予測精度向上に寄与することを目指す.

また, 東海地域では, 国土交通省によるXバンドMP レーダネットワーク（XRAIN）の運用が2010年度より 開始され, 非常に高分解能 (約 $250 \mathrm{~m}$ メッシュ, 1分間 隔）の降雨分布が得られることから，今後発生する局地 的豪雨の監視に威力を発揮することが期待されている.

本稿では, XRAIN運用開始後に名古屋周辺地域で発生 した2011年9月20日の大雨事例を用い，10分雨量データ とXRAINデータによる雨域の解析結果の比較も行う. 
こうした検討を積み重ねることにより，過去の強雨につ いての地上雨量計等による観測データと今後発生する強 雨についてのXRAINによる観測データとを同列の条件 の下で比較し，大雨特性の長期的な変化傾向等について の解析も可能になっていくものと期待される.

\section{10分雨量データとXRAINデータによる雨域解析 の比較}

東海地域におけるXRAINの運用が開始されて3年が経 過したが，本研究で対象とするのは数年に1回程度発生 寸る強雨であることから，こうした強雨のXRAINによ る観測事例が蓄積されるにはまだ相当の時間を要すると 考えられる，それ故，多くの強雨事例について雨域特性 を検討するためには，資料期間の長い地上雨量等の既存 の観測データに基づく解析を行う必要がある．本章では， XRAIN運用開始後に発生した強雨である2011年9月20日 の事例を用い，10分雨量データによる雨域の解析結果を XRAINデータと比較し，相互の関係について検討する． 2011年9月20日は，南西諸島沖を発達しながら接近し てくる台風15号による南方からの湿った気流と活発化さ れた秋雨前線の影響により, 各地で大雨となった。東海 地域では，岐阜県多治見市では総降水量496mm と2000年 9月 11 日東海豪雨時を上回る大雨が降り, 下校中の児童1 名が増水した用水路に流され死亡した．名古屋市でも北 部と東部を中心に大雨となり, 庄内川左岸で越水が発生, 一時は市内の 109 万人に避難勧告が出される事態となっ た．図-1 は降雨ピーク時の地上天気図であるが，台風 と秋雨前線の位置関係は2000年東海豪雨時と酷似してい
る，台風の動きが遅く，気圧配置がなかなか変化しな かったために長く大雨が降り続いたのも東海豪雨と共通 である。

本章の解析で使用した10分雨量データは，愛知県，名 古屋市，気象庁等が所管している雨量計173箇所の観測 データである．これらは転倒ます型雨量計であり，10分 毎のテレメータ観測值が $0.5 \mathrm{~mm}$ 又は $1 \mathrm{~mm}$ 単位で保存され ている. 雨量計の配置密度は名古屋市域で特に高く，市 の面積326.4km²に35箇所の雨量計が配置されているため, 平均して $9.3 \mathrm{~km}^{2}$ に1箇所の雨量計が配置されていること になる。

図-2 は，名古屋における降雨のピークである15:00〜 16:00の時間带について，10分毎の雨量分布を示したも のである.上段は10分雨量データから求めたものであり, 下段は1分間隔で観測されたXRAINによる降雨強度值の 10回分の平均を6で割って10分間值に換算したものであ

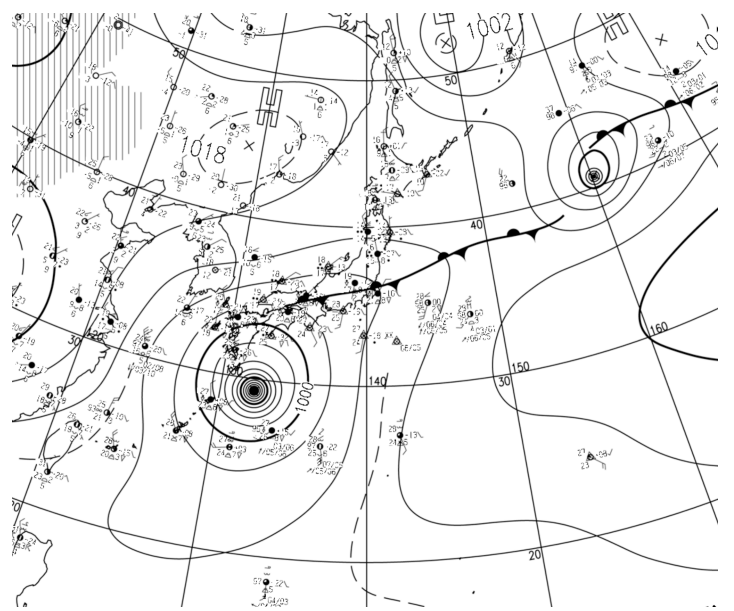

図-1 地上天気図（2011年9月20日15:00, 気象庁提供）
$15: 00-15: 10$

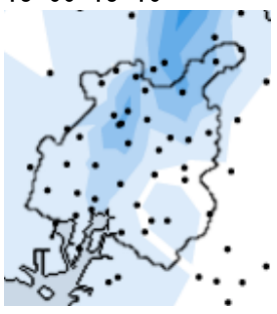

$15: 10-15: 20$

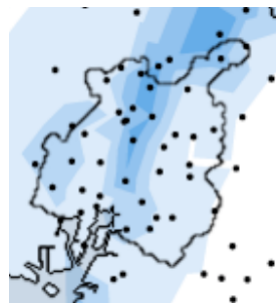

$15: 20-15: 30$

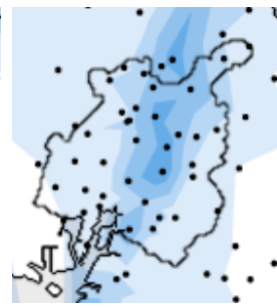

$15: 30-15: 40$

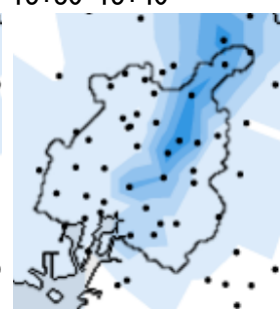

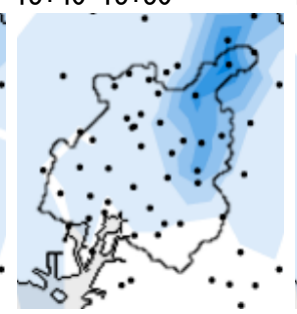

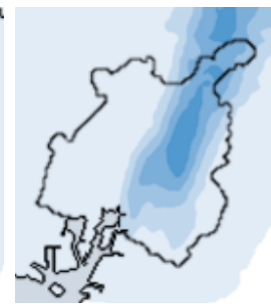

0
$15: 40-15: 50$

$15: 41-15: 50$

$15: 50-16: 00$

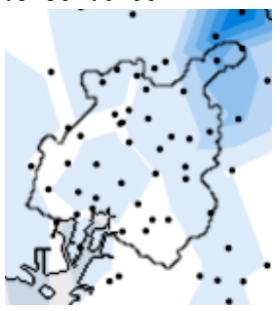

$15: 51-16: 00$

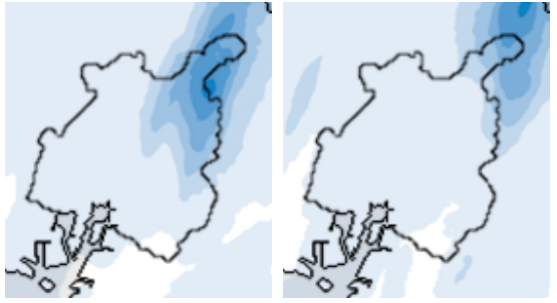

$20 \mathrm{~km} 04812162024$ (mm/10min.)

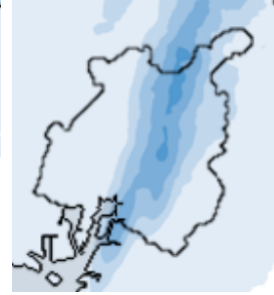

図-2 10分雨量データ（上）とXRAINデータ（下）により解析した名古屋市域における10分毎の降雨量分布 (2011年9月20日15:00 16:00)，・は雨量計の位置を表す 
る. 大きさ数 $\mathrm{km}$ 程度の降水セルが北北東の方向に次々 と移動し，带状領域の降雨域を形成している様子を見る ことができる．10分雨量とXRAINによる雨量分布図を 比較してみると，地上雨量計で捉えきれていない強雨域 が一部に見られるものの, 両者の雨量分布の位置・形状 は非常に良く一致していることが分かる.

図-3 は，個々の降水セルの移動経路を，10分雨量 データ（左）及びXRAINデータ（右）よりそれぞれ推 定し，2時間毎に3つの時間帯に分けて示したものである. また，ピーク降雨強度值を10分雨量データについては 10 分毎, XRAINデータについては5分毎にプロットの大き さで示している. 両者から推定した降水セルの出現位 置・移動方向はほぼ一致しているが，XRAINデータは 10分雨量データと比較して空間・時間分解能が格段に高 いため, より多くの降水セルについてより詳細に移動経 路を追跡できている．これらの結果から降水セルの移動 速度を計算したところ，10分雨量データでは13個の降水 セルについての平均は北北東 $\left(\mathrm{N} 25^{\circ} \mathrm{E}\right) \sim 33 \mathrm{~km} / \mathrm{h}$,

XRAINデータでは29個についての平均は北北東

$\left(\mathrm{N} 22^{\circ} \mathrm{E}\right) \sim 47 \mathrm{~km} / \mathrm{h}$ となり，対象とした6時間を通じて 大きな変化はなかった．10分雨量データとXRAINデー 夕による推定值を比較すると, 移動方向はほぼ一致して いるが，速さは10分雨量データによる推定值の方がかな り小さい．地上雨量計での観測は10分間隔であり，また 特に名古屋市域外では雨量計の配置間隔が大きいため, 降水セルの形状等が把握しにくい．そのため，10分雨量 データでは速く移動する降水セルの追跡が難しく，追跡 可能な降水セルが移動速度の比較的小さいものに偏って いる可能性が考えられる. 今後さらに事例数を蓄積し, 10分雨量データから求めた降水セルの移動速度を補正す る手法について検討していく必要があろう.

推定した降水セルの移動速度を名古屋におけるウィン ドプロファイラデータ（図-4）と比較すると，移動方向 は概社上空 $3 \sim 5 \mathrm{~km}$ 付近の風向に対応していることが分 かる．この高度における風速は40～50kt（74～93km/h） 程度であり, 降水セルの移動速度よりもかなり大きい，

図-3 より，降水セルは20日午前より長時間にわたっ て，名古屋市東部付近を通るほぼ同じ経路上を次々と通 過しており，14:00過ぎになって通過経路が名古屋市中 央部よりに移動したことが分かる．移動経路が名古屋市 東部付近で数時間停滞したのは，2000年東海豪雨時にも 見られた現象である. 記録的な豪雨となった岐阜県多治 見市付近について，通過した降水セルの個数を時間帯毎 にみると，a）10:00-12:00では5個，b) 12:00-14:00では5個， c) 14:00-16:00では0個となった. 約4時間にわたって，幅 $10 \mathrm{~km}$ 以下の狭い領域を少なくとも10個の降水セルが 次々と通過して行ったことが分かる. a) 10:00-12:00

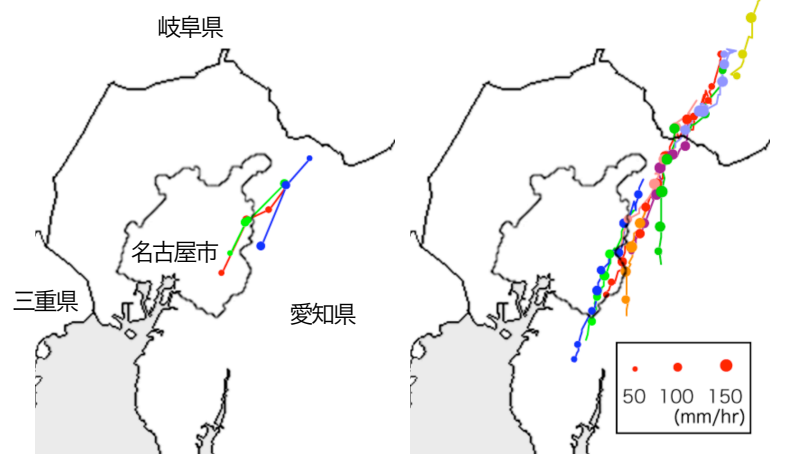

b) $12: 00-14: 00$

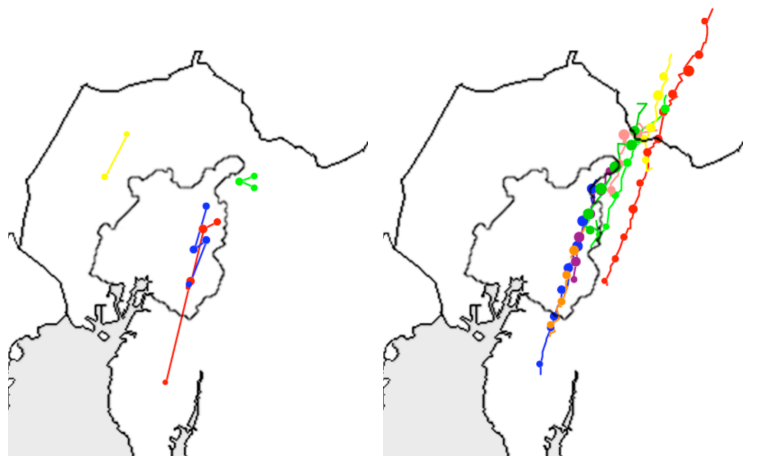

c) $14: 00-16: 00$

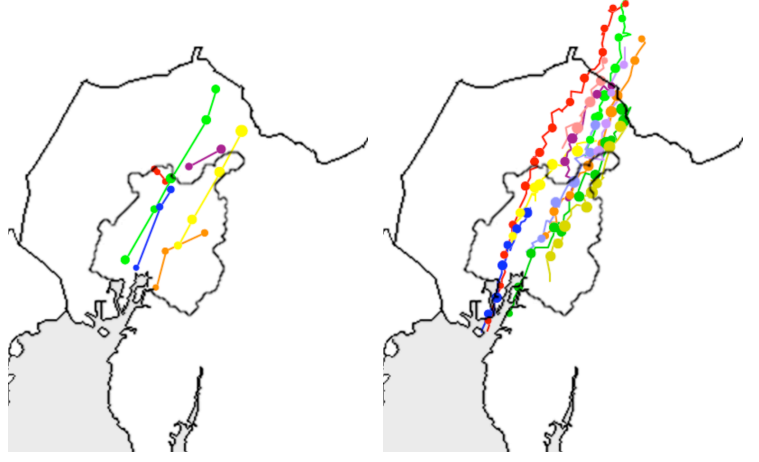

図-3 10分雨量データ（左）とXRAINデータ（右）によ り解析した降水セルの中心位置の軌跡

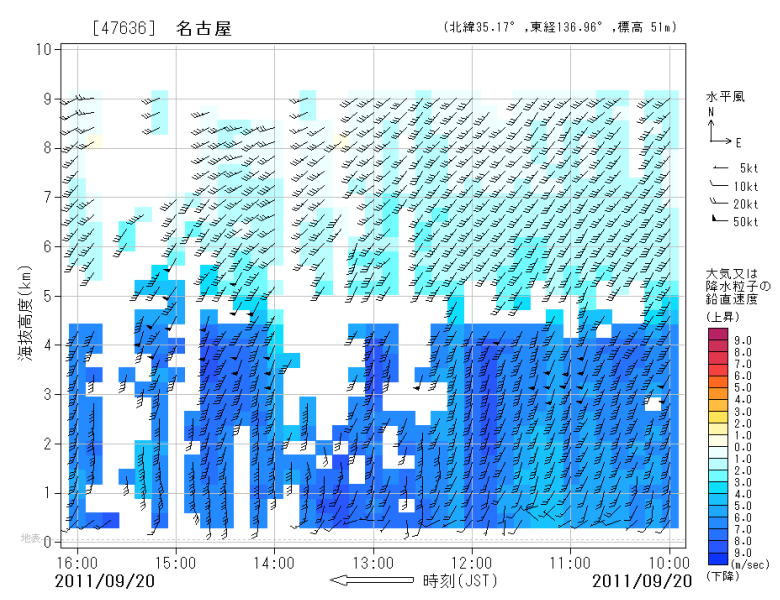

図-4 名古屋におけるウィンドプロファイラデータ (2011年9月20日10:00-16:00, 気象庁提供) 


\section{3. 名古屋における過去の強雨事例の抽出と雨域 解析}

前章において，2011年9月20日の強雨事例について10 分雨量データとXRAINデータによる雨域解析結果を比 較し，両者の結果がよく一致していること，また降水セ ルの追跡についても，10分雨量データでは移動速度が小 さめに推定される傾向があるものの，ある程度可能であ ることが示された。この結果に基づき，本章では， XRAINデータの得られない過去の強雨事例について, 10分雨量データと時間雨量データを用いて雨域特性の解 析を行い，2000年東海豪雨等と共通する特徵や相違点に つて検討する.

表-1 は，1956～2011年の56年間において，名古屋地 方気象台で観測された強雨を，最大 3 時間雨量（生起時 刻の前3時間雨量）の大きいものから10例取り出したも のである. 1976年以降はアメダスデータ，アメダス展開 前の期間については区内気象観測毎時降水量原簿を調査 した.ここで抽出された10例全てが8月末から9月に発生 しており，この地域において継続時間3時間程度の大雨 は，秋雨前線や台風に関連したものが多いことを窥わせ る.また，10例中9例までが1980年代以降に発生してい る.なお，3時間以外の様々な継続時間についても同様 の解析を行ったが，上記のような特徵は継続時間 3 時間 において最も顕著であった。

表-1 に抽出された10降雨のうち，1位（2000年9月東 海豪雨）と4位（2008年8月末豪雨）については過去に 様々な解析がなされている1),2),3),4)。 また，10位（2011年9 月20日）については前章で検討した。他の事例について も，10分雨量及び時間雨量データを用いて雨域を解析し
たところ，10例のうち9例について，2000年東海豪雨や 前章で取り上げた2011年9月20日事例と類似した，北北 東から南南西に伸びる帯状の強雨域が認められた。これ は，この地域における最大級の大雨は，梅雨前線や台風 本体などによる降雨ではなく, 主として局地的な収束線 が停滞して生じるメソ対流系5),6,7)によってもたらされる ことを示唆している.

帯状強雨域は，南東から伊勢湾に吹き込む暖湿気と内 陸の冷気塊との間で形成されるメソ収束線と密接に対応 していることが2000年東海豪雨と2008年8月末豪雨につ いて示された 1),2),3)が，そのことをより多くの事例で確認 するため, 表-1 に掲げた強雨事例のうち帯状降雨域の 認められた9事例について, 愛知県及び隣接地域におけ る地上の風向風速と気温, 強雨域の分布を解析した.

図-5 は，そのうち最大 3 時間雨量の大きい 5 事例につい て，アメダスデータと愛知県等の雨量観測データを用い, 名古屋における降雨ピーク時（最大時間雨量の生起時 刻）とその 2 時間前，2時間後における風向風速，気温及 び時間雨量の分布を重小て示したものである.なお，気 温は $6.5^{\circ} \mathrm{C} / \mathrm{km}$ で海面高度に補正し，風速は近藤ら ${ }^{8)}$ の手 法に基づき，中立安定を仮定して地上高50mの風速に換 算した。換算の際に必要となる地表面粗度の值は桑形・ 近藤 ${ }^{9) 10)}$ によったｅ）1994年9月17日を除く4事例につい ては，降雨ピーク時において気温・風速が急変する収束 線が知多半島付近を通っていることが分かる. 特に, 最 大3時間雨量1〜3位の事例 a) c c)について，帯状強雨 域の形状も酷似している.

a) 2000年9月 11 日の東海豪雨については，南北に細長 い降雨域が西の三重県方面から移動してきて, 名古屋市 東部・知多半島北部付近で数時間停滞している．特に知 多半島付近での東海豪雨の降水システムは降雨帯とメy

表-1＼cjkstart名古屋市における強雨事例（1956～2011年）

\begin{tabular}{|c|c|c|c|c|}
\hline 生起日時 & 最大 3 時間雨量 & 帯状強雨域の走向 & 降水セルの移動方向 & $\begin{array}{l}\text { 潮 岬 } 500 \mathrm{hPa} \text { ( 上 ), } \\
700 \mathrm{hPa}(\text { 下)の風向風速 }\end{array}$ \\
\hline 2000 年 9 月 11 日 21 時 & $214 \mathrm{~mm}$ & 北北東一南南西 & 北北東 & $\begin{array}{l}\text { 南南西 } 25 \text { ノット } \\
\text { 南 } 25 \text { ノット }\end{array}$ \\
\hline 1983 年 9 月 28 日 16 時 & $126 \mathrm{~mm}$ & 北北東一南南西 & - & $\begin{array}{l}\text { 南西 } 68 \text { ノット } \\
\text { 南西 } 72 \text { ノット }\end{array}$ \\
\hline 1991 年 9 月 19 日 7 時 & $123 \mathrm{~mm}$ & 北北東一南南西 & 北ないし北北東 & $\begin{array}{c}\text { 西 } 31 \text { ノット } \\
\text { 南西 } 23 \text { ノット }\end{array}$ \\
\hline 2008 年 8 月 29 日 2 時 & $121 \mathrm{~mm}$ & 北一南 & 北ないし北北東 & $\begin{array}{c}\text { 西 } 4 \text { ノット } \\
\text { 南南東 } 8 \text { ノット }\end{array}$ \\
\hline 1994 年 9 月 17 日 22 時 & $109 \mathrm{~mm}$ & 北北西一南南東 & 北北西 & $\begin{array}{l}\text { 南 } 52 \text { ノット } \\
\text { 南 } 21 \text { ノット }\end{array}$ \\
\hline 1987 年 9 月 25 日 4 時 & $107 \mathrm{~mm}$ & 北北東一南南西 & - & $\begin{array}{c}\text { 南西 } 41 \text { ノット } \\
\text { 南南西 } 39 \text { ノット }\end{array}$ \\
\hline 1999 年 9 月 14 日 23 時 & $103 \mathrm{~mm}$ & 北北東一南南西 & - & $\begin{array}{l}\text { 南南西 } 41 \text { ノット } \\
\text { 南 } 37 \text { ノット }\end{array}$ \\
\hline 2004 年 9 月 5 日 17 時 & $101 \mathrm{~mm}$ & - & - & $\begin{array}{c}\text { 南南西 } 16 \text { ノット } \\
\text { 南 } 16 \text { ノット } \\
\end{array}$ \\
\hline 1971 年 9 月 26 日 19 時 & $98 \mathrm{~mm}$ & 北一南か & - & - \\
\hline 2011 年 9 月 20 日 16 時 & $88 \mathrm{~mm}$ & 北北東一南南西 & 北北東 & $\begin{array}{l}\text { 南34ノット } \\
\text { 南 } 41 \text { ノット }\end{array}$ \\
\hline
\end{tabular}


a) 2000 年 9 月 11 日（左から 17 時、19 時、21 時）
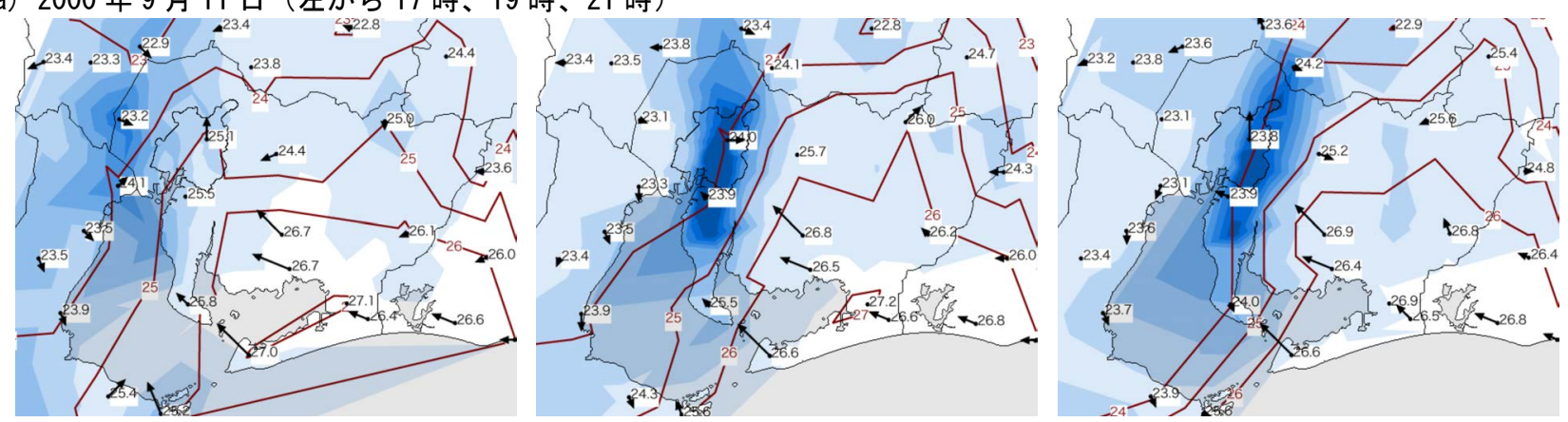

b) 1983 年 9 月 28 日（左から 14 時、16 時、18 時）

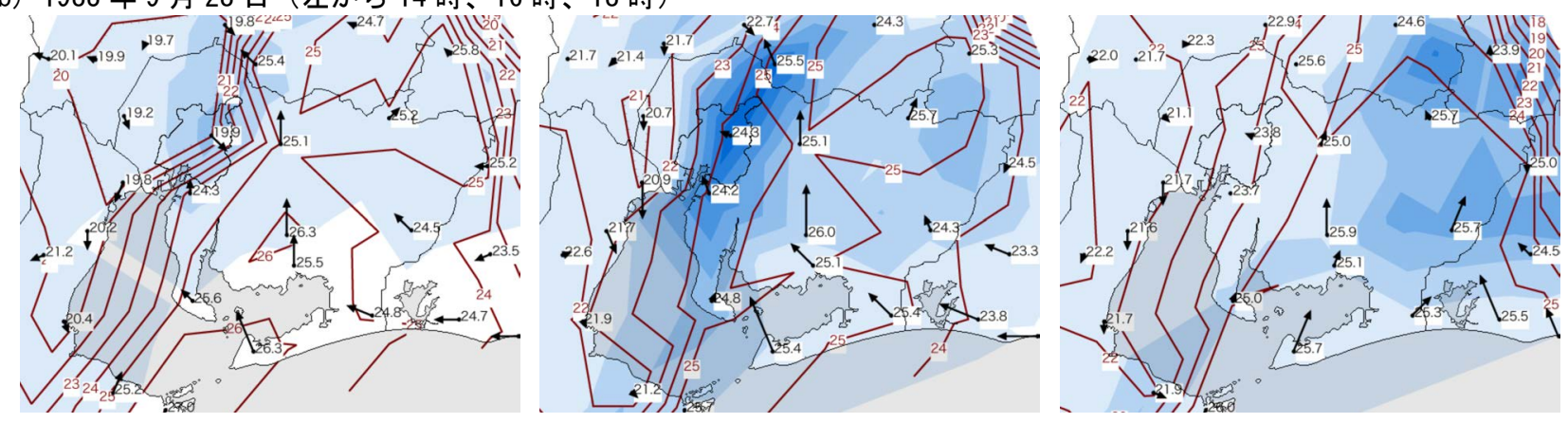

C) 1991 年 9 月 19 日（左から 5 時、7 時、9 時）
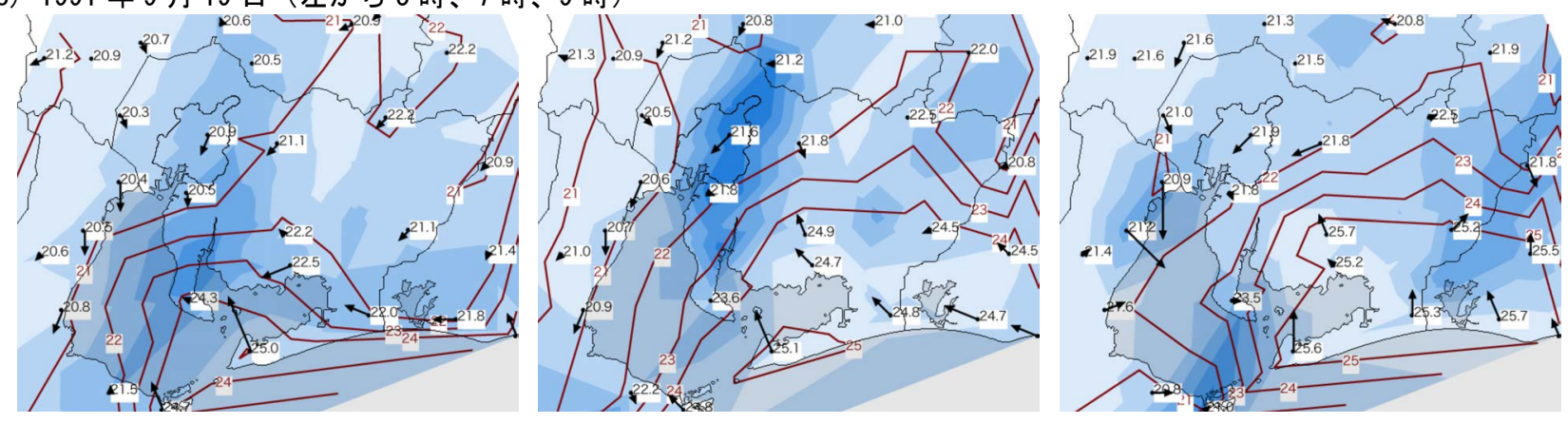

d） 2008 年 8 月 28 日（左から 22 時、24 時、29 日 2 時）
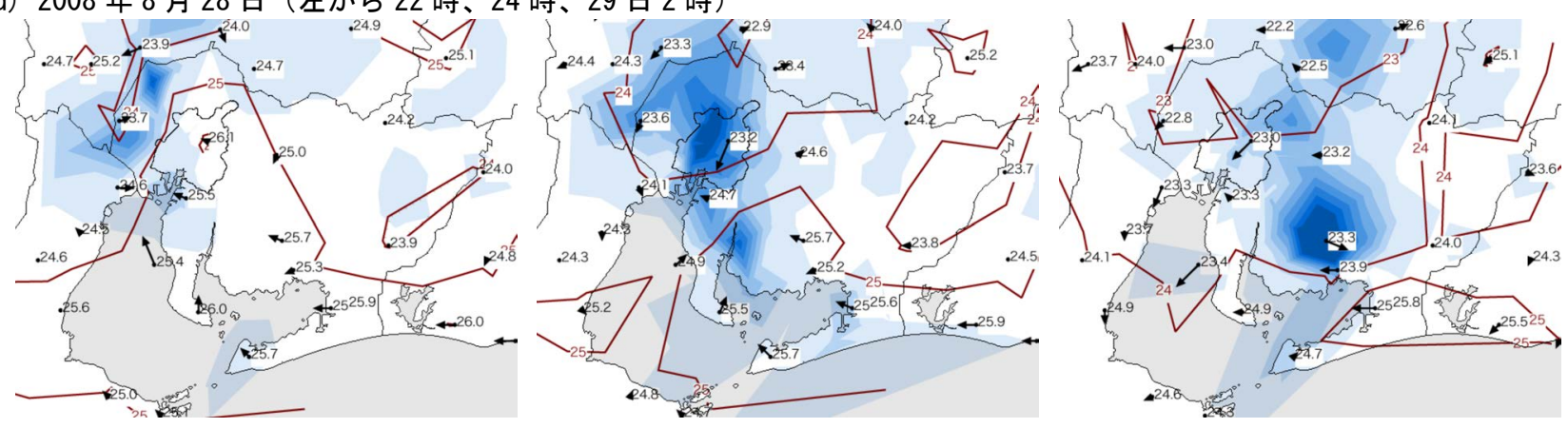

e) 1994 年 9 月 17 日（左から 19 時、21 時、23 時）
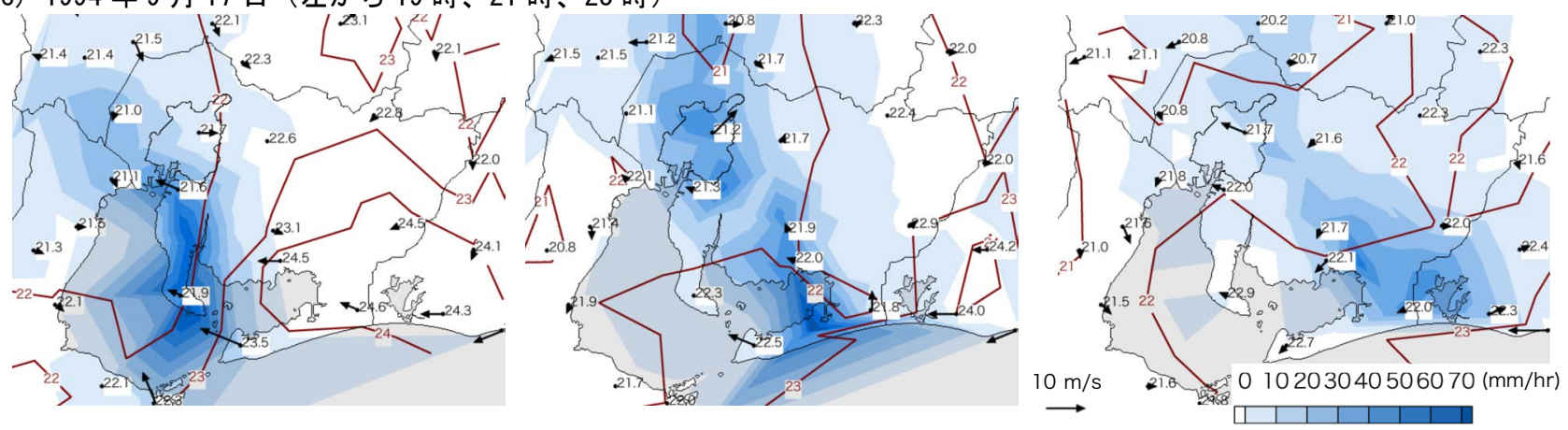

図-5 名古屋における降雨ピーク時（中央）、その 2 時間前（左）、2 時間後（右）における海面気温（数字と等值線）、風 速 (矢印)、前 1 時間雨量（グラデーション）の分布 
収束線の走向が平行なバックサイドビルディング型 ${ }^{10)} の$ 構造をしており，降雨域が衰弱せず長時間持続している。 この特徴は，b）1983年9月28日でも同様に認められる ただし，2000年東海豪雨では動きの遅い沖縄付近の台風 と南東海上の高気圧の縁辺流によって暖湿気が供給され たため，同じ場所で大雨を降らせる条件が長時間持続し たが，1983年の事例では台風から変化した温帯低気圧の 接近に伴うものであることから，地上風向等の気象条件 が短時間で変化しており，これが総雨量の大きな差と なって表れている.

c) 1991年9月19日の事例も上記2例と似通つているが, 収束線の走向が北東一南西よりとなっており，帯状強雨 域の走向と一致していない. また，南方を通過する台風 の前面で生じた暖湿気流であることから，このような条 件は長時間持続していない.

次にd) 2008年8月28～29日の2008年8月末豪雨について は，降雨域が西から近づいてくるのは東海豪雨と同様で あるが，名古屋付近に到達した降雨域はやがて衰弱し， 代わってその南側, つまり地上風の風上側に新たな降雨 域を発生させており，典型的なバックビルディング型降 雨 ${ }^{11), 12)}$ の過程を辿っている.

以上，個別の強雨事例の特徵について共通点と相違点 を見てきたが，上記の事例に共通して，名古屋における 降雨ピーク時には伊良湖及び豊橋の風向が概ね南東ない し南南東となっている. また，走向が北北東一南南西な いし北東一南西の収束線が知多半島付近を通っており, そこから北北東ないし北方に向かって帯状強雨域が伸び ている．帯状強雨域は，収束線で発生した積乱雲が上空 の風に次々と流されることによって生ずると考えられ， その走向は中層風の風向に概ね対応している. 表-1に は，10の強雨事例について，10分雨量・時間雨量データ の解析から得られた, 名古屋の降雨ピーク時における帯 状降雨域の走向, 降水セルの移動方向，及び潮岬での高 層気象観測における500hPa及び700hPaの風向風速を, データが得られたものについて示してある.

日本付近で地形に起因して線状降水帯が形成されやす い例としては九州西方の㽀島ラインや長崎ラインのが有 名であるが，名古屋から知多半島付近に形成される線状 降水帯も地形に起因したこの地方特有の現象であると著 者らは予想している. そのメカニズムの解明には, さら に事例数を増やすとともに，物理気象モデルを用いた検 討なども行っていく必要があろう.

\section{4. おわりに}

本稿では，2011年9月20日の強雨事例について10分雨 量データとXRAINデータよる雨域解析を行い, 両者の 結果がよく一致していることを確認した. そして，過去 56年間において名古屋で3時間降水量が大きい強雨事例
を抽出し，主に地上雨量データを用いた解析を行った. その結果，この地域における最大級の大雨はほぼ全て9 月に発生しており, 多くの場合にはメソ収束線に対応し た帯状の強雨域を形成していることが示された。

こうした強雨域の発生位置や強度，持続時間や移動速 度といった情報は，洪水防御計画の策定や避難・警報体 制の検討などをする際に極めて重要である.今後も事例 数を増やして検討し, 過去の観測データに基づく経験 的・統計的アプローチと物理モデルによるアプローチの 両面から局地的強雨の予測精度向上につなげていきたい と考えている. また，Xバンドに比べて分解能は落ちる が，気象庁や国土交通省のCバンドレーダーのデータも 過去に遡って入手可能であることから，その利用につい ても検討していきたい.

謝辞 : 観測データをご提供いただいた愛知県，名古屋市， 気象庁等の関係各機関に謝意を表したい. なお本研究は, (財) 河川環境管理財団名古屋事務所 調査 - 研究事業に よって実施した.

\section{参考文献}

1) 庄建治朗, 谷口健司, 冨永晃宏 : 10分雨量データを用いた 愛知県における短時間強雨の雨量解析, 水工学論文集, Vol.55, pp.S_499-S_504, 2011.

2) 渡辺真二 : 東海豪雨の観測と解析, 天気, Vol.49, pp.609619, 2002.

3）作矢朗久, 坪井嘉宏 : 2008年8月28～29日に愛知県で発生し た大雨について, 平成20年度気象学会中部支部研究会講演 要旨集, pp.57-62, 2008.

4) 小倉義光, 隈部良司, 西村修司 : 「平成20年8月末豪雨」の 天気系，特にメソ対流系の組織化について，天気，Vol.58， pp.201-217, 2011.

5) 小倉義光 : メソ気象の基礎理論, 東京大学出版会, pp.172176, 1997.

6) 吉崎正憲, 村上正隆, 加藤輝之 編 : メソ対流系, 気象研究 ノート第208号, 日本気象学会, 2005.

7) 渡辺真二, 坪井嘉宏, 肆矢朗久 : 中部地方におけるメソ対 流系の発生状況, 平成20年度気象学会中部支部研究会講演 要旨集, pp.57-62, 2008.

8) 近藤純正, 桑形恒男, 中園 信 : 地域代表風速の推定法, 自然災害科学, Vol.10, pp.171-185, 1991.

9) 桑形恒男, 近藤純正 : 東北南部から中部地方までのアメダ ス地点における地表面粗度の推定，天気，Vol.37, pp.197201, 1990.

10) 桑形恒男, 近藤純正 : 西日本アメダス地点における地表面 粗度の推定, 天気, Vol.38,pp.491-494, 1991.

11) 篠田太郎 : 集中豪雨をもたらす降水システムの構造 〜平成 20 年 8 月末豪雨を例として, 第16回日本気象学会中部支部公 開気象講座「集中豪雨」, pp.8-13, 2010.

12) 吉崎正憲, 加藤輝之 : 豪雨・豪雪の気象学, 応用気象学シ リーズ4, 朝倉書店, pp.92-115, 2007.

(2013. 9. 30受付) 